\title{
K OBSAHU A ROZSAHU VEŘEJNÝCH SUBJEKTIVNÍCH PRÁV
}

\author{
MARTIN KOPECKÝ
}

\begin{abstract}
The Attributes and Enforcement of Public Rights within Public Administration
The paper deals with the conception of public rights, their attributes, and a definition of the typical groups of public rights. The author analyses which duties of public authorities may be enforced before the court. The author further shows when individual persons have no legal claim to fulfilment of duties of public authorities. The paper analyses the evolution of public rights within the area of public administration and the possibilities of enforcement of these rights.
\end{abstract}

Keywords: public law; administrative discretion; public right; administrative supervision

Klíčová slova: veřejné právo; správní uvážení; veřejné subjektivní právo; správní dozor

DOI: $10.14712 / 23366478.2021 .36$

\section{1. ÚVOD - POJETÍ VEŘEJNÝCH POVINNOSTÍ A VEŘEJNÝCH SUBJEKTIVNÍCH PRÁV}

Veřejné povinnosti a veřejná subjektivní práva vytvářejí spolu s dalšími komponenty (jako je právní osobnost, způsobilost k právům a povinnostem, způsobilost k právním jednáním a deliktní způsobilost) právní status osoby ve veřejném právu. Veřejné povinnosti a veřejná subjektivní práva osoby, která je účastníkem administrativněprávních vztahů (správněprávních vztahů), tvoří obsah právního vztahu týkajícího se tohoto subjektu právního vztahu.

Veřejné povinnosti plynoucí ze zákona nebo existující na základě zákona, ukládající něco konat, něčeho se zdržet nebo něco strpět, jsou stanoveny jak adresátům působení veřejné moci, tak i samotné veřejné moci. $V$ tomto článku se budu primárně zaměřovat na tu veřejnou moc, která je veřejnou správou. Veřejné povinnosti se vztahují $\mathrm{k}$ jejím nositelům, ale i vykonavatelům, kterými uskutečňují jednání, které je nositeli veřejné správy prričitatelné, at' už jde o orgány těchto nositelů, či orgány jiných subjektů nebo jiné subjekty, na které byl výkon veřejné správy přenesen nebo jim byl propůjčen. Není právní normy, ze které by nevyplývala právní povinnost. ${ }^{1}$ Naopak ne z každé právní

1 Srov. HOETZEL, J. Československé správní právo: část všeobecná. Praha: Melantrich, 1934, s. 234. 
normy musí vyplývat nějaké právo - oprávnění k nějakému chování, právo na plnění od jiného a právo, aby se jiní zdrželi neoprávněného zasahování do svobodné sféry osoby. , Subjektivní povinnost jest nutným obsahem normy, subjektivní oprávnění však je možným obsahem normy. "2 Subjektivní povinnosti a práva mohou vycházet př́mo z obecné normy, mohou ale plynout i z aktů či jiných úkonů činěných na základě obecné normy obsažené nejčastěji v zákoně.

Veřejná subjektivní práva jsou závislá na právním řádu, nemohou existovat mimo objektivní právo. „Než at' již teoretická konstrukce veřejných práv subjektivních je vůbec možna a jakým způsobem jest možna, tolik zdá se jistým, že pojem subjektivního práva, i když není s pojmem objektivního práva totožný, je mu aspon̆ podřazen a na něm úplně závislý. "3

Přes různé školy, věnující se z právněteoretického pohledu otázce, jaký je vztah právního řádu, tedy práva objektivního, a subjektivních práv a povinností, s jejichž zakladateli se lze seznámit $\mathrm{v}$ uváděných citačních pramenech, lze vyjít $\mathrm{z}$ toho, že objektivní právo - právní řád - je předpokladem existence subjektivních práv neboli subjektivních oprávnění a subjektivních povinností, a co se týká veřejných subjektivních práv a povinností, tyto jsou možným obsahem veřejnoprávních právních vztahů. Č́stečné terminologické obtíže vycházejí z toho, že český výraz „subjektivní právo“, jako pojem výlučně kontinentálního práva, není př́liš vhodný, když možná př́íznačnější by bylo označení „oprávněni“, aby byl zřejmý rozdíl od „objektivního práva“. V oblasti anglo-amerického práva existují pojmy , law" pro právo objektivní a ,right “ pro právo subjektivní, takže problém jejich označení neexistuje. ${ }^{4}$ I německy píšící autoři upozorn̆ují na homonymii slova „,das Recht“, českého ekvivalentu slova „právo“, pro právo v objektivním smyslu (,, das Recht im objektiven Sinn "), jinak označované jako právní řád (,, die Rechtsordnung "), a též pro právo v subjektivním smyslu (,, das Recht im subjektiven Sinn "), označované ,,mein Anspruch “, což by bylo možné přeložit jako „můj nárok“ či „moje oprávnění“. 5

Podstatou veřejného subjektivního práva je oprávnění jednotlivce vyplývající z norem veřejného práva na zákonné postupy veřejné moci uskutečňované vůči jednotlivci alespoň částečně v jeho zájmu. ,Jednotlivcem“ lze rozumět osobu fyzickou i právnickou, a to jak soukromého, tak i veřejného práva.

\section{VEŘEJNÁ SUBJEKTIVNÍ PRÁVA V OBORU SPRÁVNÍHO PRÁVA}

Pro veřejná subjektivní práva $\mathrm{v}$ oblasti správního práva je podstatné, aby právní norma opravňovala nebo zavazovala veřejnou správu, at' už její nositele (stát či jiného nositele veřejné správy), či její vykonavatele k určitému chování, a aby daná

2 MERKL, A. Obecné právo správní. Díl první. Praha - Brno: Orbis, 1931, s. 148.

3 HÁCHA, E. Nejvyšší správní soud. In: HÁCHA, E. - HOETZEL, J. - WEYR, F. - LAŠTOVKA, K. (eds.). Slovník práva veřejného. Svazek II. Brno: Polygrafia - Rudolf M. Rohrer, 1932, s. 845.

4 Viz např. KNAPP, V. Teorie práva. Praha: C. H. Beck, 1995, s. 193.

5 Viz např. RASCHAUER, B. Allgemeines Verwaltungsrecht. 5. Aufl. Wien: Verlag Österreich, 2017, s. 398. 
pravidla ne třeba výlučně, ale minimálně také byla v zájmu jednotlivce, kterému toto subjektivní právo svědčí. ${ }^{6}$ Pro existenci subjektivního práva je důležité právní uznání existence zájmu osoby na určitém chování ze strany veřejné moci. Z právní úpravy může totiž vyplývat řada povinností veřejné správy, které jsou činěny ve veřejném zájmu, avšak bez dostatečného spojení s konkrétním zájmem jednotlivce na výkonu takových povinností. Těmto povinnostem veřejné správy neodpovídá subjektivní právo jednotlivce. Zákon může např. správnímu úřadu ukládat povinnost vydat k jeho provedení právní předpis, př́íslušný správní orgán může být oprávněn, ale současně i povinen při splnění zákonných podmínek zahájit z úřední moci přezkumné ř́zení ve vztahu k pravomocnému rozhodnutí, které bylo dle správního orgánu vydáno v rozporu s právními předpisy, avšak takovým povinnostem vykonavatelů veřejné správy zpravidla neodpovídají veřejná subjektivní práva na to, aby jednotlivec taková jednání veřejné správy vyvolal.

Pro určení okruhu subjektivních veřejných práv v podmínkách českého právního rádu je důležité, že jde o institut využívaný pro vymezení rozsahu pravomoci soudů ve správním soudnictví. Spojení „,veřejná subjektivní práva“ užívá výslovně $§ 2$ zákona č. 150/2002 Sb., soudní řád správní - SǨS (,, Ve správním soudnictví poskytují soudy ochranu veřejným subjektivním právi̊m fyzických i právnických osob [...] "). ${ }^{7}$ Kontrola správy ve správním soudnictví v tomto pojetí není všeobecnou kontrolou zákonnosti jejího rozhodování, ale slouží prioritně k ochraně práv jednotlivců vưči postupům veřejné správy, tedy ochraně veřejných subjektivních práv. Užití pojmu veřejná subjektivní práva v soudním řádu správním spočívá mj. ve významu antipodu k subjektivním právům soukromým, k jejichž ochraně soudy ve správním soudnictví pravomoc nemají, ale přichází v úvahu ochrana soudy „obecnými“, tedy v soudnictví civilním. České správní soudnictví v tomto směru navázalo na starší úpravy, vyjádřené v $§ 105$ československé ústavní listiny č. 121/1920 Sb. z. a n. ze dne 29. 2. 1920 a ještě dříve v čl. 15 státního zákona č. 144/1867 ř. z., o moci soudcovské, potažmo v $\$ 2$ odst. 1 zákona č. 36/1876 ř. z., o zřízení správního soudu. Ačkoli formálně v zákonné terminologii rakouské a pozdější československé ohledně správního soudu (rakouského správního soudního dvoru či československého nejvyššího správního soudu) spojení „veřejná subjektivní práva“ nebylo, bylo v teorii a aplikační praxi užíváno, když ze zákonného vymezení pravomoci vyplývalo, že správní soud rozhodoval v prŕípadě, kdy někdo tvrdil, že byl poškozen ve „Svých právech“, tedy právech subjektivních, rozhodnutím nebo opatřením správního úradu, přičemž v pravomoci soudu správního nebylo rozhodovat o nárocích soukromoprávních.

Stávající model soudní ochrany, kdy o sporech a jiných právních věcech, které vyplývají z poměrů soukromého práva, o nichž podle zákona rozhodl v mezích své zákonné pravomoci jiný orgán než soud, ${ }^{8}$ rozhoduje soud rozhodující v občanském soudním řízení (podle pravidel části páté zákona č. 99/1963 Sb., občanský soudní řád, v platném

6 Srov. např. DETTERBECK, S. Allgemeines Verwaltungsrecht mit Verwaltungsprozessrecht. 18. Aufl. München: C. H. Beck, 2020, s. 122.

7 Pro srovnání v německé literatuře se užívá spojení v jiném pořadí adjektiv: ,, die subjektiven öffentlichen Rechte“ - subjektivní veřejná práva. Viz např. KLUTH, W. in: WOLF, H. J. - BACHOF, O. - STOBER, R. KLUTH, W. Verwaltungsrecht I. 13. Aufl. München: C. H. Beck, 2017, s. 476 a tam citované prameny.

8 Srov. $§ 7$ odst. 1 a 2 OSR̆. 
znění - OSŘ), nemusí být neměnný. Např. věcný záměr nového občanského soudního řádu, prripravený v letech 2016 a 2017 pracovní skupinou vytvořenou Ministerstvem spravedlnosti, ${ }^{9}$ nepředpokládá, že by nová úprava převzala dosavadní model duální soudní ochrany práv ve věcech, v nichž rozhodovaly správní orgány, tedy ve věcech subjektivních práv veřejných ve správním soudnictví a ve věcech vyplývajících ze soukromého práva v občanském soudním řízení, jak bylo založeno zákony č. 150/2002 Sb. a č. 151/2002 Sb. Ani př́ípadná legislativní změna, která by přenesla soudní rozhodování ve věcech, o nichž bylo rozhodnuto jiným, tedy správním orgánem, nyní upravené v části páté OSR̆, do pravomoci soudů správních, by nic nezměnila na rozdílné povaze veřejných subjektivních práv od subjektivních práv vyplývajících ze vztahů soukromého práva. Pro srovnání: i dřivější slovenská úprava, účinná do 30. 6. 2016, obsažená v tehdejším občanském soudním řádu, počítala se zvláštní povahou soudního rozhodování v př́ípadech, kdy správní orgán rozhodl o sporu nebo o jiné právní věci vyplývající z občanskoprávních, pracovních, rodinných a obchodných vztahů - soud mohl v případě důvodnosti žalob v těchto věcech nahradit dotčený výrok správního rozhodnutí výrokem soudního rozsudku. ${ }^{10}$ Současná úprava slovenského správního soudnictví, založená zákonem č. 162/2015 z. z., správny súdny poriadok, v platném znění, naproti tomu takové zvláštní oprávnění správním soudům nesvěřje.

I podle současné úpravy poskytují soudy ve správním soudnictví ochranu proti takovým zásahům do práv prováděných veřejnou správou, které se týkají soukromoprávních věcí, ale jimž se dotčené osoby nemohou bránit v občanském soudním ř́zení. ${ }^{11}$

Veřejných subjektivních práv, kterým odpovídá povinnost veřejné moci vůči jednotlivci, se nelze vzdát, nestanoví-li zákon jinak. To je prrípad některých procesních práv, např. práva na podání odvolání, jehož se může účastník rrízení po oznámení rozhodnutí vzdát. ${ }^{12}$ Veřejná subjektivní práva jsou zásadně nepřenositelná na jinou osobu, nestanovil-li by zákon něco jiného. Subjektivní práva, která souvisejí s vlastnickým či jiným soukromým právem $\mathrm{k}$ určité věci, ${ }^{13}$ přecházejí sice s převodem nebo přechodem soukromého práva zpravidla na nabyvatele, ale toto je důsledkem změny soukromého práva, nikoli vlastním převodem veřejného subjektivního práva. ${ }^{14}$

Veřejná subjektivní práva jsou zákonným pojmem, vymezení konkrétních práv, která do skupiny těchto práv patř́í, se však vyvíjí.

9 Text dokumentu je dostupný např. zde: Věcný záměr civilního řádu soudního. In: justice.cz: civilní řád soudni [online]. [cit. 2021-07-26]. Dostupné na: https://crs.justice.cz/.

10 Srov. zejm. § 250i odst. 2 a § 250j odst. 5 zákona č. 99/1963 Sb., občanský soudní řád, ve znění účinném do 30. 6. 2017 pro Slovenskou republiku.

11 Srov. rozsudek Nejvyššího správního soudu (NSS) ze dne 4. 5. 2017, č. j. 09 As 329/2016-42 (bod 35 odůvodnění).

$12 \S 81$ odst. 2 zákona č. 500/2004 Sb., správní řád (Spř).

13 Např. právo stavebníka provést stavbu na základě stavebního povolení podle § 115 zákona č. 183/2006 Sb., o územním plánování a stavebním řádu (stavební zákon) - StavZ.

14 Viz důsledky správních aktů in rem podle $§ 73$ odst. 2 věty poslední SpŘ: ,,Jestliže je pro práva a povinnosti účastníkù určujici právo k movité nebo nemovité věci, je pravomocné rozhodnutí závazné i pro právní nástupce účastníkủ. “ 


\section{VEŘEJNÁ SUBJEKTIVNÍ PRÁVA A SPRÁVNÍ DOZOR}

Ne každé povinnosti veřejné moci odpovídá veřejné subjektivní právo na to, aby veřejná moc své povinnosti plnila. Zásadně se např. uznává, že - neplyne-li ze zákona něco jiného - neexistuje subjektivní právo jednotlivce na výkon správního dozo$r u$, tedy činnosti, ke které je správní úráad ze zákona povinen, byt' by výkon dozoru byl v zájmu takového jednotlivce (např. koupil-li si nebezpečný výrobek, který byl uveden do oběhu v rozporu se zákonem o obecné bezpečnosti výrobků). ${ }^{15}$ Správní dozor je vykonáván z úřední moci ve veřejném zájmu, a to k ochraně objektivního práva. Odrazem výkonu správního dozoru může být prospěch pro jednotlivé osoby, avšak naopak dozor může být vykonáván bez ohledu na aktivitu jednotlivců. ${ }^{16}$ Podání osob ve vztahu k výkonu dozorčího práva nezakládají subjektivní právo podatelů na to, aby orgán veřejné moci požadovaný úkon učinil.

Judikatura bývalého československého nejvyššího správního soudu vícekrát konstatovala, že „, straně nepř́sluší nárok na výkon dozorčiho práva, a její subjektivní právo odepřením výkonu onoho nemůže být porušeno ". ${ }^{17}$ I tento soud se však zabýval (výjimečnými) situacemi, vyvolanými zákonnou úpravou, které zakládaly právo na výkon správního dozoru. Tak bylo dovozeno subjektivní právo závodní rady, plynoucí ze zákona č. 144/1920 Sb. z. a n., o závodních a revírních radách při hornictví, podle něhož tato spolupůsobila při dozoru nad udržováním a prováděním hornicko-policejních ustanovení zákonných nebo úředních nařízení o ochraně dělnictva, hygieně provozu a na provádění pracovního řádu, na provádění dozoru př́slušným správním úřadem (báňským hejtmanstvím). ${ }^{18}$

\section{EXISTUJE VEŘEJNÉ SUBJEKTIVNÍ PRÁVO NA ZAHÁJENÍ ŘÍZENÍ Z MOCI ÚŘEDNÍ?}

Obecně platí, že není subjektivní právo na provádění úkonů činěných orgány veřejné správy z úřední moci, at’ už jde např. o úkony v rámci správního dozoru, v rámci či mimo správní ř́zení, na zahajování jiných řízení z moci úřední, činění aktů abstraktní povahy či faktických úkonů (např. faktických pokynů, bezprostředních zásahů či donucovacích úkonů). Absence subjektivního práva na zahájení ř́zení, které lze zahájit jen z moci úřední, i když dal potenciální účastník takového řízení správnímu orgánu podnět k zahájení, způsobuje nemožnost domáhat se zahájení ř́zení z moci úřední at' už cestou žaloby na ochranu proti nečinnosti podle $\S 79$ odst. 1 SŘS, ${ }^{19}$ či cestou ža-

\footnotetext{
15 Zákon č. 102/2001 Sb., o obecné bezpečnosti výrobků.

16 „ׁ̆́ádné provádění dohlédacího práva může sice fakticky jitti $k$ duhu i občanům (stranám), avšak to jsou pouhé reflexy, nikoli zamýšlený účel dozorčiho práva, jež se vykonává i přes protest všech zájemníkủ. " (HOETZEL, c. d., s. 335).

17 Viz nález Nejvyššího správního soudu ze dne 10. 4. 1922 (Boh. A 1290/22); z mnoha dalších srov. např. nálezy ze dne 7. 10. 1920 (Boh. A 544/1920), ze dne 15. 2. 1921 (Boh. A 714/1921) či ze dne 14. 10.1929 (Boh. A 8173/1929).

18 Viz nález ze dne 15. 5. 1929 (Boh. A 7951/1929).

19 Viz např. rozsudek NSS ze dne 8. 7. 2009, č. j. 3 Ans 1/2009-58.
} 
loby na ochranu před nezákonným zásahem, pokynem nebo donucením dle $§ 82$ SŘS. ${ }^{20}$ Konstantní je dále např. judikatura ohledně povahy př́ípisu správního orgánu, kterým sděluje, že neshledává důvody k zahájení přezkumného řízení, ${ }^{21}$ toto sdělení je pouhým sdělením úřradu straně a není rozhodnutím ve smyslu $§ 65$ SŘS; takový úkon je vyloučen z přezkoumání soudem ve správním soudnictví a žalobu proti němu podanou správní soud odmítne jako nepř́ípustnou - ani v těchto situacích nemá podatel subjektivní právo na zahájení přezkumného řízení. ${ }^{22}$

Lze se setkat se zvláštním př́ípadem, kdy neprovedeni dozorčího úkonu, které je $v$ dispozici správního orgánu, může znamenat zkrácení ve veřejném subjektivním právu jednotlivce. Přezkumné řizení, které je dozorčím prostředkem ve vztahu k pravomocným, popř. i předběžně vykonatelným správním rozhodnutím, ${ }^{23}$ může být zakončeno zastavením podle $\S 94$ odst. 4 SpŘ: jestliže po zahájení přezkumného řízení správní orgán dojde k závěru, že ačkoli rozhodnutí bylo vydáno v rozporu s právním předpisem, byla by újma, která by jeho zrušením nebo změnou vznikla některému účastníkovi, který nabyl práva $\mathrm{z}$ rozhodnutí $\mathrm{v}$ dobré víře, ve zjevném nepoměru k újmě, která vznikla jinému účastníkovi nebo veřejnému zájmu, rrízení zastaví. ${ }^{24}$

V konkrétním případu Magistrát hlavního města Prahy jako nadřízený správní orgán zahájil přezkumné řízení ve vztahu k územnímu rozhodnutí Úřadu městské části Praha 4, s odkazem na ustanovení § 94 odst. 4 SpŘ následně usnesením řízení zastavil. Osoba, která podala podnět k zahájení přezkumného řízení a byla jeho účastníkem, napadla usnesení o zastavení řizení, nebot' dle jejího názoru nebyly naplněny podmínky pro zastavení. Zatímco Městský soud v Praze usnesením žalobu odmítl, NSS rozsudkem ze dne 19. 5. 2011, č. j. 1 As 36/2011-79, toto usnesení zrušil a vyslovil závěr, Že ,, i když bylo zahájení přezkumného řizeni z moci úředni projevem absolutní volné úvahy správního orgánu, mají účastníci přezkumného řizeni legitimni očekávání na to, že $k$ zastavení přezkumného ř́zení podle $\oint 94$ odst. 4 Sp ̌r dojde jen tehdy, jsou-li k tomu naplněny zákonné di̊vody “. NSS v cit. rozsudku nevyslovil přesvědčivě, alespoň dle mého názoru, jaké veřejné subjektivní právo by mohlo být zkráceno tím, že dojde k zastavení přezkumného řízení, tedy řizení, které je projevem dozorčí činnosti správy, když zůstane zachováno původní pravomocné správní rozhodnutí. NSS argumentoval tím, že pokud již bylo přezkumné řizení zahájeno a správní orgány shledaly, že byl porušen právní předpis, může se dále postupovat pouze dvěma způsoby - bud' rízení zastavit při naplnění podmínek obsažených v $\S 94$ odst. 4 SpŘ , nebo přezkoumávané rozhodnutí zrušit nebo změnit, popřípadě zrušit a věc vrátit odvolacímu správnímu orgánu nebo správnímu orgánu prvního stupně (§ 97 odst. 3 SpŘ). Zrušující rozhodnutí je nepochybně rozhodnutím schopným zasáhnout do existujících hmotných práv účastníků původního správního řízení, nabytých pravomocným rozhodnutím správního orgánu, a lze se proti němu bránit žalobou podle $\S 65$ a násl. SŘS, NSS v cit. rozsudku vyslovil,

20 Viz napr. rozsudek NSS ze dne 31. 8. 2017, č. j. 4 As 117/2017-46.

21 Srov. § 94 odst. 1 SpŘ.

22 Viz též např. usnesení Ústavního soudu ze dne 22. 6. 2009, sp. zn. III. ÚS 1344/09.

$23 \S 94$ odst. 1 Spř.

24 Podle závěru poradního sboru ministra vnitra ke správnímu řádu č. 96 ze dne 19. 11. 2010 zastavení přezkumného řízení podle ustanovení § 94 odst. 4 SpŘ bude mít v souladu s ustanovením § 76 odst. 1 Spř formu rozhodnutí (zákon nestanoví výslovně formu usnesení). 
že ,je proto zcela v souladu s principem rovnosti účastníků ř́zení, aby se stejným způsobem mohli účastnici bránit i rozhodnutí o zastaveni přezkumného ř́zení, v př́padě, že je přezkoumávané rozhodnutí dle názoru správních orgánů v rozporu s právními předpisy, avšak při zvážení dopadů na jednotlivé účastniky a veřejný zájem a s ohledem na dobrou víru účastníka - adresáta přezkoumávaného rozhodnutí, rozhodne správní orgán o zastavení ř́zeni. “25

K prolomení pravidla, že není subjektivní právo na zahájení správního řízení, které může zahájit výlučně z moci úřední správní orgán, dospěl NSS v nedávném rozsudku z 26. 3. 2021, č. j. 6 As 108/2019-39. Rozšířený senát NSS zkoumal otázku existence subjektivního práva jednotlivce na zahájení rízení z moci úřední ve skutkové situaci, kdy vlastník pozemku, na kterém je umístěno golfové hřiště provozované jinou osobou (golfové hřiště se rozkládá i na pozemcích jiných vlastníků), považoval golfové hřiště za nepovolenou terénní úpravu a obrátil se na krajský soud se správní žalobou na ochranu před nezákonným zásahem, který spatřoval v tom, že stavební úřad nenařídil - přes podnět tohoto vlastníka - odstranění terénních úprav, jimiž bylo zrrízeno golfové hřiště, ani neučinil žádné jiné opatření $\mathrm{k}$ nápravě protiprávní existence těchto terénních úprav. Jde o to, že správní řízení o odstranění stavby, resp. přiměřeně i terénní úpravy nebo zařízení, prováděné nebo provedené bez rozhodnutí nebo opatření vyžadovaného stavebním zákonem nebo bez opatření nebo jiného úkonu toto opatření nahrazující anebo v rozporu s ním, nebyla-li stavba (terénní úprava, zařízení) dodatečně povolena, lze zahájit výhradně z moci úřední (o tom se nevedou spory). ${ }^{26}$ „Stavba porušujicí normy veřejného práva může mít však v takovém př́padě př́mý dopad do práv vlastnika pozemku, na kterém sporná stavba stojí, eventuálně do práv souseda " (vlastníka sousedních nemovitostí) ${ }^{27}$ možnost ochrany práv vlastníka cestou civilní žaloby 28 je omezena na ochranu proti neoprávněným stavbám, nikoli proti stavbám nepovoleným ve smyslu veřejného práva - zde poskytují ochranu stavební úřady v řízení o odstranění stavby. ${ }^{29}$ NSS dovodil, že proti pasivitě stavebního úřadu, který nezahájí v rozporu se zákonem rízení o odstranění stavby, se může osoba, jejíchž hmotných práv se stavba dotýká, bránit zásahovou žalobou dle $\S 82$ a násl. SŘS.$^{30}$ Lze shrnout, že NSS dovodil pro př́ípady, kdy je nečinností veřejné správy spočívající v nezahájení řízení (popř. neučinění jiného úkonu z moci úřední) dotčeno hmotné právo osoby, subjektivní veřejné právo takové osoby na zahájení rízení z moci úrední. NSS v cit. rozsudku uvádí, že tento právní názor je třeba vykládat restriktivně, když pravidlem (s podanými výjimkami) zůstává, že uplatnění podnětu, ve kterém podatel vyzývá správní úruad k uplatnění úřední povinnosti (úřední moci), žádné veřejné subjektivní právo nezakládá. ${ }^{31}$

NSS v cit. rozsudku připustil možnost, aby se dotčený vlastník bránil proti nezákonnému nezahájení rízení o odstranění stavby žalobou proti nezákonnému zásahu za podmínky, že přímým důsledkem nečinnosti správního orgánu je též neposkytnutí

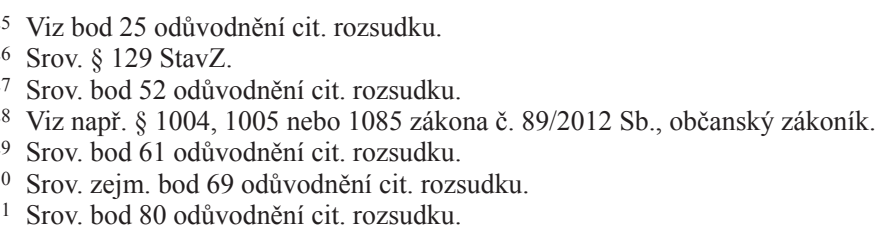


ochrany právu subjektivnímu, svědčícímu žalobci, ${ }^{32}$ dále že bude respektována zásada subsidiarity zásahové žaloby (nesmí existovat žádné jiné správní ř́izení ani žádný jiný moment, kdy osoba $\mathrm{v}$ minulosti nebo teprve $\mathrm{v}$ budoucnu bude moci chránit své subjektivní hmotné právo $\mathrm{v}$ rámci veřejné správy nebo žalobou před správním soudem), ${ }^{33}$ rovněž že se nebude ze strany žalobce jednat o zneužití práva podat správní žalobu. ${ }^{34}$

Př́ípady, kdy bude moci být dovozeno subjektivní právo na zahájení správního rrízení z úřední moci, by měly být jen výjimečné, jak vyplývá i z cit. rozsudku rozššřeného senátu. Možná by bylo vhodnější, aby se i zákonodárce zamýšlel nad př́ípady, která řízení, zahajovaná nyní výlučně z moci úřední, by mohla zahajovat svým podáním i osoba, která může být neprovedením úředního úkonu př́mo zasažena ve svých hmotných právech, jak je tomu např. v rozebíraném řízení o odstranění „nepovolené“ stavby.

Je otázkou, zda nebyl nastolen zmíněným rozsudkem trend v možnosti domáhat se zásahovou žalobou zahájení ř́zení i v jiných než v rozsudku předvídaných př́padech. K posouzení např. je, zda by možnost podat zásahovou žalobu neměla mít osoba př́mo postižená spácháním přestupku, ${ }^{35}$ nezahájí-li v rozporu s principem legality správní orgán přes její podnět ř́zení o přestupku. Přitom okruh osob př́mo postižených spácháním přestupku obsahově odpovídá okruhu osob, které byly oprávněny podle předchozí úpravy přestupkového práva, účinné do 30. 6. 2017, zahájit svým návrhem přestupkové rízení. ${ }^{36}$

\section{KATALOG VEŘEJNÝCH SUBJEKTIVNÍCH PRÁV}

Katalog veřejných subjektivních práv se vývojem postupně mění a (zpravidla) rozšiřuje. $V$ minulosti např. nebylo dáno veřejné subjektivní právo tam, kde nebyl úřad s ohledem na svou volnou úvahu povinen vyhovět žádosti. ${ }^{37}$ Od absolutního či neomezeného správního uvážení se však zpravidla upustilo. I v těch př́ípadech, kdy správní orgán rozhoduje na základě svého uvážení a žadatel nemá nárok na vyhovění jeho žádosti, jako je např. ve věci žádosti o udělení státního občanství, ${ }^{38}$ o odstranění tvrdosti zákona ${ }^{39}$ či prominutí daně a obdobných finančních povinností, ${ }^{40}$ je správní orgán povinen respektovat zákaz libovůle, princip rovnosti, zákaz diskriminace, princip proporcionality, čemuž odpovídají i veřejná subjektivní práva účastníka řízení na to, aby vydané rozhodnutí tyto principy respektovalo. ${ }^{41}$

\footnotetext{
Srov. bod 83 odůvodnění cit. rozsudku.

Srov. bod 85 odůvodnění cit. rozsudku.

Srov. bod 88 odůvodnění cit. rozsudku.

3571 zákona č. 250/2016 Sb., o odpovědnosti za přestupky a řízení o nich.

6 Viz $§ 68$ odst. 1 zákona č. 200/1990 Sb., o přestupcích.

37 Např. $§ 248$ odst. 2 písm. i) OSŘ, ve znění do 31. 12. 2002, vylučoval ve správním soudnictví soudní přezkum rozhodnutí o žádostech na plnění, na něž není právní nárok, nebo o žádostech o odstranění tvrdosti zákona, zejména rozhodnutí finančních orgánů o úlevách na odvodech, daních a poplatcích.

38 Srov. § 12 zákona č. 186/2013 Sb., o státním občanství České republiky.

39 Viz např. rozsudky NSS ze dne 12. 8. 2009, č. j. 3 Ads 123/2008-79, či ze dne 25. 11. 2009, č. j. 3 Ads 82/2009-113.

40 Srov. např. zákon č. 280/2009 Sb., daňový řád (zejména § 259 a 260); zákon č. 250/2000 Sb., o rozpočtových pravidlech územních rozpočtu (§ 22 odst. 14).

41 Srov. např. usnesení rozšířeného senátu NSS ze dne 23. 3. 2005, č. j. 6 A 25/2002-42; a nález Ústavního soudu ze dne 22. 7. 2009, sp. zn. III. ÚS 2556/07.
} 
Základem pro existenci veřejných subjektivních práv mohou být právní normy obsažené $\mathrm{v}$ pramenech různé právní síly, at' už v ústavním pořádku, mezinárodních smlouvách, zákonech či právu EU. Ne z každého v Listině základních práv a svobod (Listina) formulovaného základního práva a svobody vyplývá subjektivní právo, resp. veřejné subjektivní právo, jež by bylo právně prosaditelné vi̊či veřejné moci. Co se týká práv uvedených v čl. 41 odst. 1 Listiny (z katalogu hospodářských, sociálních a kulturních práv), je možné se jich domáhat pouze $\mathrm{v}$ mezích zákonů, které ustanovení Listiny o těchto právech provádějí. ${ }^{42} \mathrm{I} v$ př́padě práv vyjmenovaných $\mathrm{v}$ čl. 41 odst. 1 Listiny musí být zákony, které provádějí ustanovení o těchto právech, šetřeno jejich podstaty a smyslu (čl. 4 odst. 4 Listiny). ${ }^{43}$ Za podmínek stanovených Listinou mohou být upraveny meze základnich práv a svobod, tedy tato práva mohou být omezena, a to pouze zákonem. Taková zákonná omezení základních práv a svobod musí platit stejně pro všechny př́pady, které splňují stanovené podmínky, při používání ustanovení o mezích základních práv a svobod musí být šetřeno jejich podstaty a smyslu a omezení nesmějí být zneuživána $\mathrm{k}$ jiným účelům, než pro které byla stanovena. ${ }^{44} \mathrm{Z}$ Listiny vychází rovněž řada práv, která mají povahu subjektivních práv soukromých, např. právo vlastnit majetek, zaručení dědického práva, právo, aby byla zachována lidská důstojnost, osobní čest, dobrá pověst a chráněno jméno. ${ }^{45}$

Veřejná subjektivní práva vyplývající z „běžných“ zákonů nebývají, jak je to typické pro práva a svobody základní, vždy výslovně vyjádřena, ale jejich existenci lze dovodit např. z povinnosti veřejné správy postupovat vůči jednotlivci jen určitě stanoveným způsobem, poskytovat mu při splnění zákonných podmínek vymezená plnění atd.

Soudní praxe se věnuje velmi často posuzování, zda z právní normy vyplývá určité veřejné subjektivní právo, zda mu náleží ochrana ve správním soudnictví, případně v soudnictví jiném (civilním, trestním či ústavním). Pro pochopení, jaká vlastně veřejná subjektivní práva existují, je důležité pokusit se o jejich typové rozdělení do jejich jednotlivých skupin. V komentáŕi k soudnímu řádu správnímu z roku 2004, na jehož první vydání bohužel nenavázalo vydání další, bylo vymezeno, že ,, veřejná subjektivní

42 Jedná se např. o právo podle čl. 35 odst. 1 Listiny (, Každý má právo na přiznivé životní prostředi. “). Dle čl. 41 odst. 1 Listiny je možné se práva na příznivé životní prostředí domáhat nikoli abstraktně podle Listiny, ale jen v mezích zákonů o životním prostředí, nedotčeny zůstávají přitom úpravy vyplývající z mezinárodních smluv. Viz např. nález Ústavního soudu ze dne 10. 7. 1997, sp. zn. III. ÚS 70/97.

43 Srov. např. nález Ústavního soudu ze dne 15. 2. 1994, sp. zn. Pl. ÚS 35/93 (k otázce nepodmíněnosti práva na bezplatné vzdělání v základních a středních školách dle Listiny). Dalším příkladem je nález ze dne 20. 5. 2008, sp. zn. Pl. ÚS 1/08, kterým byl zamítnut návrh skupiny poslanců na zrušení části zákona č. 261/2007 Sb., o stabilizaci veřejných rozpočtů - část zdravotnická, mj. ve věci návrhu na zrušení regulačních poplatků ve zdravotnictví - podle nálezu lze v kombinaci s požadavkem plynoucím z čl. 4 odst. 4 Listiny vytyčit 4 kroky vedoucí k závěru o ústavnosti či neústavnosti zákona, jenž provádí ústavně garantovaná sociální práva: 1) vymezení smyslu a podstaty sociálního práva, tedy určitého esenciálního obsahu (zde čl. 31 odst. 1 Listiny: , Každý má právo na ochranu zdraví. Občané mají na základě veřejného pojištění právo na bezplatnou zdravotni péči a na zdravotni pomi̊cky za podminek, které stanovi zákon. "); 2) zhodnocení, zda se zákon nedotýká samotné existence sociálního práva nebo jeho skutečné realizace (esenciálního obsahu). Pokud se nedotýká esenciálního obsahu sociálního práva, dále 3) posouzení, zda zákonná úprava sleduje legitimní cíl; tedy zda není svévolným zásadním snížením celkového standardu základních práv, a konečně 4) zvážení otázky, zda zákonný prostředek použitý k jeho dosažení je rozumný (racionální), byt' nikoli nutně nejlepší, nejvhodnější, nejúčinnější či nejmoudřejší.

44 Čl. 4 odst. 2, 3 a 4 Listiny.

45 Srov. čl. 10 odst. 1 a čl. 11 odst. 1 Listiny. 
práva jsou práva osob založená v právních normách, která umožňují a současně chrání určité chováni ve vztazich $k$ subjektiom verejné správy. Podle jejich obsahu je lze rozlišovat na práva směřujicí k tomu, aby se veřejná správa zdržela zásahů do svobody osob, dále práva na určitou činnost či plněni správy ve prospěch určitých osob a práva podilet se na správě věci veřejných. "46 Toto základní, spíše užší vymezení rozsahu veřejných subjektivních práv, bylo převzato i v judikatuře, když bylo ve více rozhodnutích citováno. ${ }^{47}$ To, že je potřebné pokusit se rozsah veřejných subjektivních práv vymezit nad rámec citovaného vymezení, vyplývá např. z toho, že veřejná subjektivní práva se nemusí vztahovat jen $\mathrm{k}$ hmotněprávnímu postavení osoby, ale mohou mít čistě procesní význam v rámci určitého postupu orgánu veřejné správy, a dále nap̌r. z toho, že existují veřejná subjektivní práva samosprávných (decentralizovaných) nositelů veřejné správy na participaci na výkonu veřejné správy.

Do demonstrativního výčtu lze řadit tyto skupiny veřejných subjektivních práv: a) právo na získání veřejnoprávního oprávnění

Do této skupiny se řadí množství práv na to, aby veřejná správa vydala při splnění zákonem daných podmínek povolení k určité činnosti, např. řidičské oprávnění, stavební povolení, udělila oprávnění $\mathrm{k}$ činnosti, na které má žadatel nárok.

b) právo na poskytnutí veřejných plnění

Do této skupiny lze řadit napřr. právo na poskytování dávek důchodového pojištění, podpory v nezaměstnanosti, vrácení nadměrného odpočtu na dani z přidané hodnoty, ale třeba i právo žadatele na poskytnutí informace dle zákona o svobodném přístupu $\mathrm{k}$ informacím.

c) právo na řádné odůvodnění správniho uvážení

V souvislosti s odstupem od dřívějš́ koncepce absolutní volné úvahy správního orgánu, kdy správní orgán se musí i v těch př́ípadech, kdy má zákonem vymezený prostor pro své uvážení, ř́́dit nezbytnými pravidly (např. zákonem stanovenými kritérii správního uvážení, neužívat naopak nepř́ípustná kritéria, dodržovat pravidla o předvídatelnosti a proporcionalitě rozhodování), a když i obecným požadavkem na vydávaná rozhodnutí je jejich odůvodnění, ${ }^{48}$ existuje právo dotčené osoby na to, aby rozhodnutí vydávané vůči ní bylo odůvodněno, a to i v těch př́ípadech, kdy se domáhá přiznání určitého práva, na které nemá právní nárok. ${ }^{49}$

d) právo, aby se veřejná moc zdržela nepř́ípustných zásahů do svobodné sféry jednotlivce

Jedná se o velmi rozsáhlý a rozmanitý okruh práv osob vůči veřejné správě, resp. veřejné moci, jako odraz ústavního pravidla, že státní moc lze uplatňovat jen v prŕípadech, v mezích a způsobem, které stanoví zákon. ${ }^{50}$ Prosazuje se v př́ípadech, kdy

46 VOPÁlKA, V. - MIKULE, V. - ŠIMU゚NKOVÁ, V. - ŠOLÍN, M. Soudni rád správní: komentářr. Praha: C. H. Beck, 2004, s. 3.

47 Viz rozsudek NSS ze dne 30. 9. 2004, č. j. 2 As 22/2004-68, odkaz na právní názor z tohoto rozsudku uvádí napřr. rozsudek NSS ze dne 15. 10. 2019, č. j. 8 As 269/2019-27.

48 Viz $§ 68$ odst. 3 Sp $\breve{R}$.

49 Pro srovnání: v německé literatuře se píše o nároku - požadavku osoby na rozhodnutí s bezchybným uvážením úřadu (,, der Anspruch auf fehlerfreie Ermessensentscheidung “) - viz MAURER, H. - WALDHOFF, CH. Allgemeines Verwaltungsrecht. 20. Aufl. München: C. H. Beck, 2020, s. 185.

50 Viz čl. 2 odst. 4 Ústavy. 
veřejná moc zasahuje do svobodné sféry jednotlivce tím, že mu ukládá povinnosti nebo zákazy, odnímá nebo omezuje nabytá oprávnění, např́íklad při ukládání správních trestů, odnímání oprávnění k podnikatelské činnosti, ustanovování nucené správy atd.

e) právo na vznik, změnu nebo zánik vztahů veřejného práva

Do této skupiny lze řadit např. právo vypovědět veřejnoprávní smlouvu, byla-li tato možnost dohodnuta, ${ }^{51}$ právo př́slušníka bezpečnostního sboru na skončení jeho služebního poměru na základě žádosti o propuštění, ${ }^{52}$ právo státního občana České republiky na pozbytí státního občanství České republiky prohlášením o vzdání se státního občanství, ${ }^{53}$ právo na povolení změny př́ijmení, je-li pro to vážný důvod. ${ }^{54}$

f) procesni práva

Procesní práva, která náleží podle právní úpravy správního řízení účastníkům řízení, spoluurčují status těchto osob. Porušení některých práv může mít dopad i do jejich hmotněprávního postavení, může-li mít takové porušení vliv na zákonnost rozhodnutí o věci samé, ${ }^{55}$ některá subjektivní práva, která náleží účastníkům řízení, mají naproti tomu význam jen v rámci rízení samého a jejich př́padné porušení ze strany správního orgánu nedosahuje takové intenzity, že by se bylo možné úspěšně domoci nápravy cestou opravného prostředku nebo ve správním soudnictví. Subjektivní práva obdobné povahy náleží dotčeným osobám i v rámci jiných postupů veřejné správy, např. při postupech podle zákona o kontrole. K procesním právům se řadí např. právo být seznámen $\mathrm{s}$ obsahem spisu, právo vyjádřit se $\mathrm{k}$ podkladům rozhodnutí, právo být poučen o svých právech, právo podávat opravné prostředky dle zákona atd. ${ }^{56}$

g) právo na řádný výkon úřední činnosti z moci úřední, má-li výkon této moci přmý dopad do práv dotčené osoby a není-li jiný nástroj ochrany těchto práv

Jak bylo ukázáno výše, existenci takového subjektivního práva připustila pro výjimečné př́pady judikatura Nejvyššího správního soudu (viz rozbor možnosti podat žalobu proti nezákonnému zásahu $\mathrm{v}$ př́ípadě, kdy stavební úřad nezákonně nezahájí řízení o odstranění stavby).

h) právo na účast na výkonu veřejné moci, včetně práva na rovný prístup $k$ voleným a jiným veřejným funkcím a na ochranu před protiprávním zbavením veřejné funkce Do této skupiny subjektivních práv se řadí např. aktivní a pasivní volební právo dle jednotlivých volebních zákonů a právo na ochranu mandátu. ${ }^{57}$ Existence veřejného subjektivního práva na rovné podmínky př́istupu $\mathrm{k}$ voleným a jiným veřejným funkcím a na zákaz diskriminace byla přiznána např. $\mathrm{v}$ rozhodnutích vydaných $\mathrm{v}$ rámci žaloby uchazeče o výkon funkce soudce - justičního čekatele proti prezidentu re-

51 Viz $§ 166$ odst. 2 Spř.

52 Viz § 42 odst. 1 písm. m) a odst. 5 písm. c) zákona č. 361/2003 Sb., o služebním poměru př́ílušníkủ bezpečnostních sborů.

53 Viz § 40 odst. 1 zákona č. 186/2013 Sb., o státním občanství České republiky.

54 Viz $\$ 72$ odst. 2 zákona č. 301/2000 Sb., o matrikách, jménu a př́ijmení (srov. též rozsudek NSS ze dne 11. 5. 2011, č. j. 1 As 26/2011-55).

55 Srov. např. § 76 odst. 1 písm. c) SŘS.

56 Viz např. KOPECKÝ, M. Správní právo: obecná cást. 2. vyd. Praha: C. H. Beck, 2021, s. 351-352.

57 Viz např. § 91 SŘS. 
publiky na ochranu proti nečinnosti spočívající v nevydání rozhodnutí o návrhu na jmenování justičního čekatele soudcem, a to i když sám uchazeč návrh na projednání věci (na své jmenování) podat nemohl. ${ }^{58}$ Ochrana před protiprávním zbavením veřejné funkce, tedy před odvoláním z funkce, $\mathrm{k}$ němuž nejsou zákonné podmínky, byla přiznána např. v ř́zení, kdy Ústavní soud zrušil rozhodnutí prezidenta republiky o odvolání předsedkyně Nejvyššího soudu z funkce, ${ }^{59}$ dále např. při posuzování postupu odvolání vedoucích státních zástupců, při němž musí být dodržen zákonný postup a dány zákonné důvody. ${ }^{60}$

ch) subjektivní veřejná práva na výkon svěrených samosprávných úkolů

Veřejná subjektivní práva nenáleží jen adresátům působení veřejné moci, ale i jejím nositelům, a to především veřejnoprávním korporacím. Jedná se o práva na výkon samosprávy, který je veřejnoprávním korporacím zákonem, v př́ípadě územních samosprávných celků př́padně i Ústavou, svěřen. Povahu subjektivního práva má právo územních samosprávných celků, tvořených územními společenstvími občanů, na samosprávu. Toto subjektivní právo, zaručené čl. 8 Ústavy, je chráněno vedle jiných způsobů - i zvláštní, tzv. komunální ústavní stížností orgánů územní samosprávy proti nezákonnému zásahu státu. ${ }^{61}$ Veřejná subjektivní práva na výkon samosprávy náleží ale i dalším veřejnoprávním korporacím, což se projevuje např. v možnosti ochrany před nezákonnými zásahy správních úřadů, které mohou spočívat např. v neudělení souhlasu k platnosti statutárních předpisů, který požadují některé zákony. ${ }^{62}$ Naproti tomu výkon výsostné správy veřejnoprávních korporací vůči jejím adresátům (např. výkon disciplinární pravomoci vi̊či členům profesních komor) není výkonem veřejného subjektivního práva, ale realizací jejich působnosti (kompetence). ${ }^{63}$

\section{ZÁVĚR}

Článek se pokusil, na základě teoretických poznatků, zákonné úpravy i poznatků z rozhodovací praxe, ukázat na význam veřejných subjektivních práv a na proměny jejich obsahu a rozsahu. Pochopení, kdy zákonem vyslovené právo jednotlivce znamená soudně prosaditelné veřejné subjektivní právo a kdy povinnostem ukládaným $\mathrm{k}$ výkonu veřejné moci jsou přiřaditelná veřejná subjektivní práva (a kdy ne), je důležité nejen z pohledu koncepce správního soudnictví existujícího i případně reformovaného,

58 Viz rozsudky NSS ze dne 27. 4. 2006, č. j. 4 Aps 3/2005-35, a ze dne 21. 5. 2008, č. j. 4 Ans 9/2007-197.

59 Viz např. nález Ústavního soudu ze dne 12. 9. 2006, sp. zn. II. ÚS 53/06.

60 Viz např, rozsudek NSS ze dne 27. 10. 2009, č. j. 9 As 22/2004-68.

61 Čl. 87 odst. 1 písm. c) Ústavy.

62 Např. s pravomocí Ministerstva spravedlnosti udělovat souhlas jako podmínku platnosti kancelářského řádu, kárného řádu a zkušebního řádu, které přijímá Notářská komora ČR, souvisí veřejné subjektivní právo Notářské komory ČR na udělení takového souhlasu, požádá-li o něj Notářská komora ČR a neodporuje-li takový statutární předpis zákonu - srov. § 37 odst. 4 zákona č. 358/1992 Sb., o notáŕích a jejich činnosti (notářský řád).

63 Srov. RASCHAUER, c. d., s. 406. 
ale má význam i pro koncepci procesních postupů veřejné správy, zejména však pro vymezení obsahu statusu osob ve veřejném právu.

Pozornost právní teorie i aplikační praxe by měla být věnována především rozboru katalogu veřejných subjektivních práv a nastavení pravidel, jakým povinnostem veřejné moci odpovídá určité subjektivní právo jednotlivce, a kdy tomu tak naopak není.

prof. JUDr. Martin Kopecký, CSc.

Právnická fakulta Univerzity Karlovy

kopecky@prf.cuni.cz 